\title{
Deep $\mathrm{N}$ fertilizer placement mitigated $\mathrm{N}_{2} \mathrm{O}$ emissions in a Swedish field trial with cereals
}

\author{
Katrin Rychel • Katharina H. E. Meurer (iD - Gunnar Börjesson • \\ Monika Strömgren • Gizachew Tarekegn Getahun • Holger Kirchmann • \\ Thomas Kätterer
}

Received: 11 November 2019/ Accepted: 10 August 2020/Published online: 25 August 2020

(C) The Author(s) 2020

\begin{abstract}
Deep fertilizer placement is a proposed strategy to increase crop yield and nitrogen $(\mathrm{N})$ use efficiency while decreasing nitrous oxide $\left(\mathrm{N}_{2} \mathrm{O}\right)$ emissions from soil to atmosphere. Our objective was to test three fertilization depth orientations to compare overall $\mathrm{N}$ use efficiency, based on a 2-year field trial on a mineral soil cropped with cereals in Uppsala, Sweden. The field was fertilized with ammonium nitrate at a rate of $120 \mathrm{~kg} \mathrm{ha}^{-1}$ (2016) and $105 \mathrm{~kg} \mathrm{ha}^{-1}$ (2017) and a deep fertilizer placement (DP) at $0.20 \mathrm{~m}$ was compared to a shallow placement (SP) at $0.07 \mathrm{~m}$ and a mixed-depth placement (MP) where fertilizer was halved between the depths of 0.07 and $0.20 \mathrm{~m}$, and a non-fertilized control (NF). In 2016, compared to SP, MP and DP increased $\mathrm{N}$ content in harvested grain by $3.6 \%$ and $2.5 \%$ respectively, and DP increased grain yield by $11 \%$
\end{abstract}

Electronic supplementary material The online version of this article (https://doi.org/10.1007/s10705-020-10089-3) contains supplementary material, which is available to authorized users.

K. Rychel · K. H. E. Meurer $(\bowtie) \cdot$ G. Börjesson · M. Strömgren · G. T. Getahun · H. Kirchmann Department of Soil and Environment, Swedish University of Agricultural Sciences, Box 7014, 75007 Uppsala, Sweden

e-mail: katharina.meurer@slu.se

T. Kätterer

Department of Ecology, Swedish University of Agricultural Sciences, Box 7044, 75007 Uppsala, Sweden
$(P<0.05)$. In both years, $\mathrm{N}_{2} \mathrm{O}$ emissions were similar in DP and NF, whereas SP and MP emissions were similar but generally higher than those in DP and NF. Fertilizer-induced emission factors (EF) for the growing season of 2017 decreased with fertilizer placement depth and were $0.77 \pm 0.07,0.58 \pm 0.03$, and $0.10 \pm 0.02$ for SP, MP, and DP, repectively. Although deep $\mathrm{N}$ placement benefits are likely dependent on weather conditions and soil type, this strategy has a clear potential for mitigating $\mathrm{N}_{2} \mathrm{O}$ emissions without adversely affecting yield.

Keywords Nitrous oxide - Deep N fertilization Nitrogen use efficiency $\cdot$ Fertilizer $\mathrm{N}$ placement

\section{Introduction}

The intensification and expansion of agriculture is on a course for rapid increase as the Earth will need to support a projected additional two billion people by 2050 (United Nations 2019). The use of mineral nitrogen $(\mathrm{N})$ fertilizer directly and indirectly contributes to the microbial production of the greenhouse gas (GHG) nitrous oxide $\left(\mathrm{N}_{2} \mathrm{O}\right)$ via soil and water systems. The residence time of $\mathrm{N}_{2} \mathrm{O}$ in the atmosphere is about 120 years and is 265 times more potent as a GHG compared to carbon dioxide $\left(\mathrm{CO}_{2}\right)$ on a 100 -year time scale (Myhre et al. 2013). Atmospheric $\mathrm{N}_{2} \mathrm{O}$ is either removed by a sink via microbial reduction or 
transported to the stratosphere and consumed in an ozone-depleting chemical reaction, making it one of the most dominant sources of ozone depletion (Ravishankara et al. 2009).

$\mathrm{N}_{2} \mathrm{O}$ is produced by two processes, nitrification and denitrification, which occur under oxic and anoxic conditions, respectively. The former process is primarily mediated by autotrophic bacteria from the genera Nitrosomonas and Nitrosospira, and strictly a source of $\mathrm{N}_{2} \mathrm{O}$. The latter process, however, can be either $\mathrm{N}_{2} \mathrm{O}$-consuming or $\mathrm{N}_{2} \mathrm{O}$-producing. Though $\mathrm{N}_{2} \mathrm{O}$ is naturally emitted, the trend of increasing emissions is due to human activities, of which around $60 \%$ comes from agriculture (Smith et al. 2014), inherently connected to the use of nitrogenous fertilizers. The near quarter-fold increase in atmospheric $\mathrm{N}_{2} \mathrm{O}$ since the industrial revolution is attributed to a widening use of mineral $\mathrm{N}$ fertilizer (Park et al. 2012). Fertilization is vital for food security and cannot be excluded from crop production, necessitating a sharp focus on identifying fertilizer application strategies that can mitigate $\mathrm{N}_{2} \mathrm{O}$ emissions. While surfaceapplied fertilizer can lead to $\mathrm{N}$ losses from both ammonia $\left(\mathrm{NH}_{3}\right)$ volatilization (Pan et al. 2016) and microbial nitrification and denitrification (Cameron et al. 2013), increasing fertilizer placement depth is a method for improving current agricultural practices, with potential to increase overall nutrient use efficiency (NUE).

Furthermore, temperature and moisture are major controls on soil $\mathrm{N}$ turnover, availability and mobility, affecting $\mathrm{N}$ losses via leaching and gaseous losses derived from nitrification and denitrification (Godde and Conrad 1999; Robinson 2002). Wet-dry cycles in soil induce pulses of $\mathrm{N}$ and carbon (C) mineralization upon re-wetting (Schimel 2018), of which the upper topsoil is most affected via rainfall events that mobilize fertilizer $\mathrm{N}$. The amplitude of temperature and moisture variability decreases with increasing soil depth. Increasing fertilizer placement depth may be an effective method for keeping plant available $\mathrm{N}$ over longer periods with less rainfall due to more constant soil moisture conditions.

A deeper fertilizer placement may even improve crop growth over standard shallow or surface placements. Crop roots tend to proliferate around the area of the fertilizer grain, thus deeper placement can promote root length density and enhance $\mathrm{N}$ uptake (Lotfollahi et al. 1997; Li et al. 2009) as well as water utilization
(Singh et al. 1976) from deeper soil layers. Crops can obtain more than two thirds of their nutrition from deeper layers in the soil profile when nutrient availability and/or water is limited in the topsoil (Kautz et al. 2013) and deep fertilization could improve plant growth, particularly during periods of little to no precipitation. On the contrary, and particularly under high water availability, deeper placements have been shown to both increase (e.g. Ke et al. 2018) and decrease (e.g. Grant et al. 2019) N leaching and the amount of mineral $\mathrm{N}$ in the soil layers below the fertilizer placement.

Previous studies have indicated that augmenting the residence time of the gas in the soil matrix can decrease the $\mathrm{N}_{2} \mathrm{O}: \mathrm{N}_{2}$ ratio, either by entrapment (Harter et al. 2016) or by lengthening the path of diffusion from the "source" of denitrification, i.e., location of the fertilizer grains to the soil surface (Clough et al. 1998). In studies where microbial $\mathrm{N}_{2} \mathrm{O}$ uptake was observed, it tended to be in cases where soil moisture limited gas diffusion through the soil matrix, particularly in the absence of mineral $\mathrm{N}$ (Chapuis-Lardy et al. 2007). Thus, with deeper placement of fertilizer, the distance for $\mathrm{N}_{2} \mathrm{O}$ diffusion from the fertilization layer to the soil surface would be increased, meaning a longer residence time and a potentially increased reduction of $\mathrm{N}_{2} \mathrm{O}$ to $\mathrm{N}_{2}$ in the upper zone of the topsoil where no fertilizer $\mathrm{N}$ was placed. Furthermore, deep placement concentrates fertilizer- $\mathrm{NH}_{4}{ }^{+}$into localized areas, stimulating methane $\left(\mathrm{CH}_{4}\right)$ oxidation by soil methanotrophs and reducing $\mathrm{CH}_{4}$ emissions (Bodelier et al. 2000a, b). Deeper root growth promoted by fertilizer placement increases the oxygen availability in the rhizosphere which is likely to enhance $\mathrm{CH}_{4}$ consumption in deeper layers (Gilbert and Frenzel 1998; Kruger et al. 2001).

Previous field studies showed that deep fertilizer placement, compared to broadcast application, increased yields, improved NUE, and decreased N runoff (Mengel et al. 1982; Kelley and Sweeney 2007; Xia et al. 2016; Zhu et al. 2019). Regarding $\mathrm{N}_{2} \mathrm{O}$ emissions, however, results are rather contradicting: while deep $\mathrm{N}$ fertilizer placement effectively lowered $\mathrm{N}_{2} \mathrm{O}$ emissions in rice paddies (Gaihre et al. 2015; Wu et al. 2017) and field experiments comparing conservation tillage methods (Liu et al. 2006; Nash et al. 2012), other studies (e.g. Cai et al. 2002; Drury et al. 2006; Chu et al. 2007) found that $\mathrm{N}_{2} \mathrm{O}$ emissions were higher from deeper $\mathrm{N}$ placement compared to shallow 
$\mathrm{N}$ placement. In terms of $\mathrm{CH}_{4}$ emissions, deep $\mathrm{N}$ placement has been found to be a promising management practice with regard to $\mathrm{CH}_{4}$ mitigation (Linquist et al. 2012). However, the studies summarized by Linquist et al. (2012) focussing on the impact of $\mathrm{N}$ fertilizer placement on $\mathrm{CH}_{4}$ emissions have been conducted in rice systems, which were either continuously flooded or rainfed. Methane measurements under different fertilizer depth management under cereals are still scarce.

The local agronomic practice in central Sweden prescribes a sub-surface placement of fertilizer around $0.07 \mathrm{~m}$ during seeding, which in many studies is already considered a "deep" placement. In this study, $0.07 \mathrm{~m}$ depth of fertilizer placement was considered as a baseline in comparison to considerably deeper placements. We tested the effect of three different mineral $\mathrm{N}$ fertilizer placements representing a shallow $(0.07 \mathrm{~m})$, deep $(0.20 \mathrm{~m})$, and mixed placement (half at $0.07 \mathrm{~m}$, half at $0.20 \mathrm{~m}$ ) along with a non-fertilized control on crop growth, yield, and $\mathrm{N}_{2} \mathrm{O}$ and $\mathrm{CH}_{4}$ emissions on a conventionally farmed mineral soil in Central Sweden. We expected that the two deeper fertilizer placements (deep and mixed) would have a positive effect on overall $\mathrm{N}$ use efficiency, improve crop yield, and lower $\mathrm{N}_{2} \mathrm{O}$ and $\mathrm{CH}_{4}$ emissions (Linquist et al. 2012; Xia et al. 2016). The mixed placement could elucidate if crops benefited from two placement depths for both early and later plant growth stages, but also if $\mathrm{N}_{2} \mathrm{O}$ and $\mathrm{CH}_{4}$ emissions were affected by the presense of an overlaying unfertilized zone acting as a buffer or sink.

\section{Materials and methods}

Site characteristics and experimental setup

A 2-year experiment was established in the spring of 2016 in Säby $\left(59^{\circ} 83^{\prime} \mathrm{N}, 17^{\circ} 71^{\prime} \mathrm{E}\right)$, near Uppsala, Sweden on a Eutric Cambisol that has been used as cropland for at least a century. The site has a silt loam texture in the topsoil and is composed of $21.2 \%$ clay, $55.7 \%$ silt, $23.1 \%$ sand, and $6.1 \mathrm{pH}_{\mathrm{H} 2 \mathrm{O}}$. The climate is cold temperate with a mean annual air temperature of $5.5{ }^{\circ} \mathrm{C}$ and precipitation of $528 \mathrm{~mm}$ (Table 1), of which $215 \mathrm{~mm}$ occur during the growing season (May-August).
In May 2016 prior to planting we sampled soil from a $20 \mathrm{~m}$ long $\cdot 1.5 \mathrm{~m}$ deep pit running parallel to the experimental plots where $241.5 \mathrm{~m}$-deep soil columns had been removed from the field. Total soil organic carbon (SOC) and total nitrogen (TN) concentrations were analysed via dry combustion (LECO CNS Analyser, LECO Corporation, St. Joseph, MI, USA) using bulked samples taken down to $1 \mathrm{~m}$ depth at $0.10 \mathrm{~m}$ intervals at three points along the length of the pit (Table 2).

In 2016, the field was sown at a rate of $238 \mathrm{~kg} \mathrm{ha}^{-1}$ with spring wheat (Triticum aestivum L.var. 'Quarna') and fertilized with ammonium nitrate at a rate of $120 \mathrm{~kg} \mathrm{~N} \mathrm{ha}^{-1}$. The following year spring barley (Hordeum vulgare L. var. 'Makof') was sown at a rate of $200 \mathrm{~kg} \mathrm{ha}^{-1}$ and fertilized with $105 \mathrm{~kg} \mathrm{~N}^{-1}$ ammonium nitrate. The fertilizer used in both years was YaraBela AXAN (Yara International, Oslo, Norway). The plots were sown and fertilized simultaneously using a Combi drill with the ability to adjust fertilizer and seed depth (Spirit 400C Strip Drill, Väderstad, Sweden), with two available fertilizer outlets allowing for split-level placement in the same vertical plane. Seed row spacing was $0.125 \mathrm{~m}$ and the fertilizer was incorporated into one or two $0.05 \mathrm{~m}$ wide bands (depending on the treatment) below the seedbed. The general agronomic practice for the area is to place seeds at approximately $0.05 \mathrm{~m}$ and fertilizer at $0.07 \mathrm{~m}$ depth, so that the sub-surface soil moisture will promote seed germination without the reliance on subsequent rainfall. In 2017, because sowing depth was shallow $(\leq 0.03 \mathrm{~m}$ ) and planting occurred before a period without rainfall, seed emergence was greatly delayed in many plant rows. Irrigation is rarely used in this area, but due to poor seed emergence, plots were irrigated once after sowing with an equivalent of $17 \mathrm{~mm}$ rainfall on June 22nd (Fig. 1). The fields are typically cultivated in the fall, but after the 2017 growing season, a $4 \mathrm{~m}$ wide $\times 64 \mathrm{~m}$ long strip where the chambers had been previously established during the growing season was left uncultivated to facilitate further GHG measurements. However, field conditions after fall cultivation, particularly after rainfall and subsequent accumulation of snow and ice and then initial melt, rendered the field inaccessible and the planned GHG measurements were unobtainable for much of the autumn and winter of 2017-2018. 
Table 1 Mean air temperature $\left({ }^{\circ} \mathrm{C}\right.$ ) and sum of precipitation (mm) during the growing season in 2016 and 2017 (May-August), and climate normal in Uppsala (1961-1990); data from Ultuna meteorological station

\begin{tabular}{|c|c|c|c|c|c|c|}
\hline & \multicolumn{2}{|l|}{2016} & \multicolumn{2}{|l|}{2017} & \multicolumn{2}{|c|}{ Climate normal (1961-1990) } \\
\hline & May-Aug & Annual & May-Aug & Annual & May-Aug & Annual \\
\hline Temperature $\left({ }^{\circ} \mathrm{C}\right)$ & 15.1 & 6.9 & 14.6 & 6.6 & 14.2 & 5.5 \\
\hline Precipitation (mm) & 208 & 443 & 197 & 507 & 215 & 528 \\
\hline
\end{tabular}

Table 2 Total C (TC) and total N (TN) (\%) along the soil profile sampled in spring 2016 prior to fertilization and sowing

\begin{tabular}{llll}
\hline Soil depth (m) & TC \% & TN \% & n \\
\hline $0-0.10$ & $2.83 \pm 0.08$ & $0.24 \pm 0.005$ & 3 \\
$0.10-0.20$ & $2.66 \pm 0.12$ & $0.22 \pm 0.010$ & 3 \\
$0.20-0.30$ & $1.43 \pm 0.58$ & $0.12 \pm 0.050$ & 3 \\
$0.30-0.40$ & $0.66 \pm 0.26$ & $0.06 \pm 0.030$ & 3 \\
$0.40-0.50$ & $0.39 \pm 0.01$ & $0.04 \pm 0.002$ & 2 \\
$0.50-0.60$ & $0.35 \pm 0.03$ & $0.04 \pm 0.004$ & 3 \\
$0.60-0.70$ & $0.38 \pm 0.01$ & $0.05 \pm 0.001$ & 3 \\
$0.70-0.80$ & $0.33 \pm 0.02$ & $0.04 \pm 0.003$ & 3 \\
$0.80-0.90$ & $0.64 \pm 0.02$ & $0.09 \pm 0.004$ & 3 \\
$0.90-1.00$ & $0.65 \pm 0.02$ & $0.09 \pm 0.003$ & 3
\end{tabular}

Values are given as mean \pm standard error. $n=$ number of samples

The experimental setup followed a randomized block design with four repetitions of four treatments corresponding to three depths of fertilizer placement plus a non-fertilized control. Experimental plots were $4 \times 20 \mathrm{~m}$ and consisted of an unfertilized control treatment $(\mathrm{NF})$, a shallow placement of fertilizer at $0.07 \mathrm{~m}$ (SP), a deep placement at $0.20 \mathrm{~m}$ (DP) and mixed placement (MP) where half of the fertilizer was placed at $0.07 \mathrm{~m}$ and the other half at $0.20 \mathrm{~m}$.

\section{GHG flux measurements}

Immediately after the fields were seeded and fertilized, a $0.55 \times 0.35 \mathrm{~m}$ steel frame with a water well welded to its top and a $0.10 \mathrm{~m}$ lip underneath was pressed into the soil in the middle of each plot. Frames were centered encompassing the same number of crop rows, and the first gas measurement was performed within 24 h. Plant number and seed emergence within frames was monitored and found to be consistent across all plots. Before harvest, frames were removed from the plots to avoid damage from agricultural equipment during combine harvesting and fall tillage. Static chamber measurements were performed by placing opaque polypropylene chambers $(0.57 \times 0.37$ $\times 0.23 \mathrm{~m}$ ) into the water-filled well on top of the frames. In the second year, each chamber was additionally equipped with a ventilation tube and a small battery-powered axial fan for air mixing within the chamber during sampling. When the chamber height became insufficient as crops grew taller, a riser, constructed from a similar plastic box as the chamber, but with the bottom removed, was added to the underside of the chamber to prevent crop damage and increase air movement during GHG measurements.

At each sampling occasion, chambers were closed for approximately $45 \mathrm{~min}$ and sampled five times at $10 \mathrm{~min}$ intervals beginning at time of closure. Air samples were collected using the flow-through method where air was circulated for one minute between the chamber, a $20 \mathrm{ml}$ glass collection vial, and an air pump connected in a loop with tygon tubing. Air temperature inside the chamber was monitored during gas flux measurements. Thereafter, gas sample vials were stored at room temperature and analyzed within a week simultaneously for $\mathrm{N}_{2} \mathrm{O}$ and methane $\left(\mathrm{CH}_{4}\right)$ concentration on a gas chromatograph (Clarus 500, Perkin Elmer, USA) equipped with an FID and ECD using an automatic headspace injector (Turbo Matrix 110, Perkin Elmer, USA). In the first year, eight gas flux measurements were performed during the growing season (between 18 May-27 July) timed to occur immediately following the initial fertilization and significant rainfall events. The following year, the measurement scheme was intensified so that ten measurements were performed within the first 2 weeks after sowing, two measurements per week were done during the subsequent 2 weeks, followed by weekly or biweekly measurements during the rest of the growing season. Measurements were timed to occur 


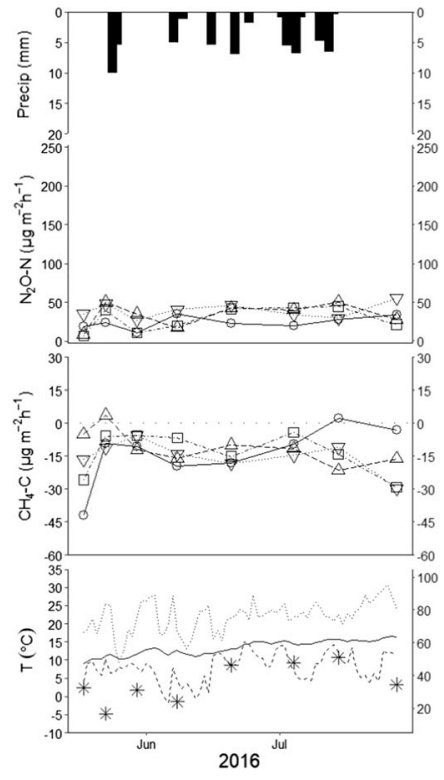

Fig. 12016 and 2017 cropping seasons daily precipitation and irrigation $(\mathrm{mm})$, mean treatment nitrous oxide fluxes $\left(\mu \mathrm{g} \mathrm{N}_{2} \mathrm{O}-\right.$ $\mathrm{N} \mathrm{m}^{-2} \mathrm{~h}^{-1}$ ), methane fluxes $\left(\mu \mathrm{g} \mathrm{CH}_{4}-\mathrm{C} \mathrm{m}^{-2} \mathrm{~h}^{-1}\right.$ ), maximum and minimum air temperature*, soil temperature at $0.10 \mathrm{~m}$ soil depth* and soil water content (\% WFPS) at 0-0.05 m soil depth. For clarity, error bars have been excluded from gas concentration values but can be found in supplementary material

immediately following periods of rainfall or irrigation when possible. In addition, three measurements were done during a two-week period of spring thaw in April 2018, following the second cropping season.

Due to logistical reasons, only the measurement period in 2017 includes the whole cropping season, while measurements are limited to eight occasions in 2016 and three occasions in the spring of 2018. Trends and significant differences between the $\mathrm{N}$ placements will be discussed for the cropping periods in 2016 and 2017.

Biomass sampling and analysis

Above-ground biomass was sampled by hand at harvest and twice mid-season, at stem elongation and at heading, approximately Zadok's growth stage (ZGS) 32 and 52, respectively, in 2016. In 2017 plant biomass was collected at harvest and at booting, approximately ZGS 45 . The biomass was collected by removing all above-ground crop biomass within a $0.5 \times 0.5 \mathrm{~m}$ metal frame randomly placed at four locations within each plot. Grain biomass was measured both in the hand-harvested small plots and in a net plot of $34.8 \mathrm{~m}^{2}$ in the center of each plot that was combine harvested. Collected biomass was dried, threshed at harvest, ground and analysed for $\mathrm{N}$ content on an organic elemental combustion instrument (LECO, USA). One to two days prior to each midseason biomass collection, leaf chlorophyll was measured using a hand-held SPAD-502 m (Minolta Camera Co., Osaka, Japan). Four plants within four randomly chosen areas within each plot were selected, and four measurements were made on the first fully expanded leaf at the top of the selected plant. During SPAD measurements, sixteen plants within each plot were randomly chosen for measuring plant height.

Soil measurements

On gas sampling days, soil moisture was measured with a Theta probe (Delta-T Devices, Cambridge, UK) to a depth of $0.05 \mathrm{~m}$ at four locations both inside and outside the frames. Observed soil moisture was converted to water-filled pore space (WFPS). Soil temperature, as depicted in Fig. 1, was accessed from 
a nearby climate station (Funbo-Lövsta) and was not measured at the field site. In the second year, plots were sampled to $0.40 \mathrm{~m}$ depth and soil cores were subdivided into $0.05 \mathrm{~m}$ depth increments to $0.30 \mathrm{~m}$, and one at $0.30-0.40 \mathrm{~m}$ for analysis of mineral $\mathrm{N}$ content by $2 \mathrm{~m}$ potassium chloride $(\mathrm{KCl})$ extraction followed by colorometric determination on a segmented flow analyzer (SEAL AutoAnalyzer 3, Seal Analytical, UK). Composite soil samples were collected on three occasions from each plot, prior to fertilization, 39 days after fertilization and immediately following harvest.

\section{Calculations and statistical analyses}

The R-software R 3.4.4 (RStudio Team 2018) was used for statistical analyses. Differences between treatments, i.e. fertilizer placements, were investigated by repeated measures Anova, i.e. a linear mixedeffects model using the lme function (nlme package, Pinheiro et al. 2019) with the repetitions as random factor and the log-likelihood maximized method "ML". Analysis of variance was done with the Anova function (car package, Fox and Weisberg 2019). Posthoc analysis was done by Tukey's all pair comparisons and using the glht function (multcomp package, Hothorn et al. 2008). Differences were regarded significant for $P<0.05$. We used a linear regression to check for climate effects (e.g., WFPS) on $\mathrm{N}_{2} \mathrm{O}$ and $\mathrm{CH}_{4}$. In addition, a linear model consisting of per-plot mean WFPS, mid-season soil mineral N (0$0.20 \mathrm{~m}$ ), and mean $\mathrm{N}_{2} \mathrm{O}$ or $\mathrm{CH}_{4}$ from 2017 to check for combined soil water and $\mathrm{N}$ effects on $\mathrm{GHG}$ emissions. Figures were made using ggplot from the ggplot 2 package (Wickham 2016) and plot_grid from the cowplot package (Wilke 2019). Nitrous oxide and $\mathrm{CH}_{4}$ fluxes were determined from concentration increase or decrease inside the chambers and using the $\mathrm{R}$ package gasfluxes (Fuss 2019) using the "robust linear" flux calculation method. Cumulative GHG fluxes for the three measurement periods (2016 and 2017 cropping seasons and 2018 spring thawing period) were calculated by linear interpolation between the days when measurements were taken using the aggfluxes function from the aforementioned gasfluxes R package (Fuss
2019). The fertilizer-induced seasonal emission factor (EF), which evaluates the amount of $\mathrm{N}_{2} \mathrm{O}$ emissions that result from anthropogenic $\mathrm{N}$ inputs into soils, was calculated over the growing season for all three fertilized treatments according to

$E F_{N_{2} O-N}[\%]=\frac{\left(N_{2} O_{\text {fert }}\left[\mathrm{kg} \mathrm{Nha}^{-1}\right]-N_{2} O_{\text {unfert }}\left[\mathrm{kgNha}^{-1}\right]\right)}{\left.N_{\text {applied }}\left[\mathrm{kgNha}^{-1}\right]\right)} * 100$,

with $\mathrm{N}_{2} \mathrm{O}_{\text {fert }}=$ cumulative $\mathrm{N}_{2} \mathrm{O}$ fluxes from fertilized treatment, $\mathrm{N}_{2} \mathrm{O}_{\text {unfert }}=$ cumulative $\mathrm{N}_{2} \mathrm{O}$ flux from unfertilized treatment, and $N_{\text {applied }}=$ amount of applied fertilizer $\mathrm{N}$. Yield-scaled $\mathrm{N}_{2} \mathrm{O}$ emissions were calculated following Venterea et al. (2011):

$N_{2} O_{\text {yield }}=\frac{N_{2} O_{\text {fert }}\left[\mathrm{kg} \mathrm{Nha}^{-1}\right]}{\text { grain yield }\left[\mathrm{kg} \mathrm{Nha}^{-1}\right]}$

The $\mathrm{N}$ surplus (potential $\mathrm{N}$ loss to the environment) was calculated for each treatment as the difference between $\mathrm{N}$ inputs ( $\mathrm{N}$ in seed and fertilization) and outputs ( $\mathrm{N}$ in harvested grains and straw, as well as $\mathrm{N}$ losses in the form of $\mathrm{N}_{2} \mathrm{O}$ ). The nitrogen use efficiency (NUE) gives an indication of resource efficiency (Quemada et al. 2020) and was calculated as

$$
\begin{aligned}
\text { NUE }[\%]= & \left(\frac{\sum\left(\text { crop N outputs }\left[\mathrm{kg} \mathrm{N} \mathrm{ha}^{-1}\right]\right)}{\sum\left(N \text { fertilizer inputs }\left[\mathrm{kg} \mathrm{Nha}^{-1}\right]\right)}\right) \\
& * 100
\end{aligned}
$$

However, as this measure only concerns the fertilized treatments, we calculated the agronomic efficiency of $\mathrm{N}\left(\mathrm{AE}_{\mathrm{N}}\right)$, which is the ratio of yield to $\mathrm{N}$ supply (Lahda et al. 2005) and the recovery efficiency of $\mathrm{N}\left(\mathrm{RE}_{\mathrm{N}}\right)$, which is the ratio of plant $\mathrm{N}-\mathrm{N}$ supply (Lahda et al. 2005; Dobermann 2005). Both $\mathrm{AE}_{\mathrm{N}}$ and $\mathrm{RE}_{\mathrm{N}}$ take the unfertilized control into consideration:

$$
\begin{aligned}
& A E_{N}\left[\mathrm{~kg} \mathrm{~kg}^{-1}\right]=\frac{\left(\text { grain yield }_{\text {fert }}-\text { grain yield }_{\text {unfert }}\right)}{N_{\text {applied }}}
\end{aligned}
$$

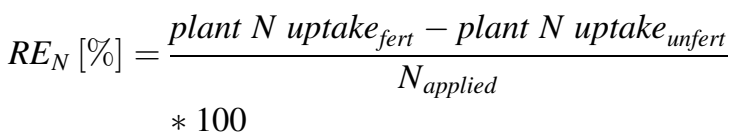




\section{Results}

\section{Environmental conditions}

The growing seasons in 2016 and 2017 were slightly warmer than normal and precipitation was slightly lower than normal $(215 \mathrm{~mm})$, particularly in the earlier part of the season of 2017 (Table 1; Fig. 1).

WFPS measured at $0.05 \mathrm{~m}$ ranged from 17 to $51 \%$ in 2016 with the lowest value in late May and the highest value in mid July. In 2017, observed WFPS was lower than in the previous year with the lowest value $(9.6 \%)$ observed in late July and the highest value $(65.7 \%)$ observed in mid September. We found no correlations between WFPS and soil mineral $\mathrm{N}$ content or $\mathrm{N}_{2} \mathrm{O}$ emissions in any of the measurement periods.

Greenhouse gas emissions

\section{Nitrous oxide}

Fertilizer placement depth affected cumulative $\mathrm{N}_{2} \mathrm{O}$ emissions during the two growing seasons in 2016 and 2017 (Fig. 2). Compared with the control NF, N fertilization resulted in an increase in cumulative $\mathrm{N}_{2} \mathrm{O}$ emissions, between $32-61 \%$ in 2016 and $10-70 \%$ in 2017. In 2016, cumulative $\mathrm{N}_{2} \mathrm{O}$ emissions were significantly highest in SP, and MP and DP were

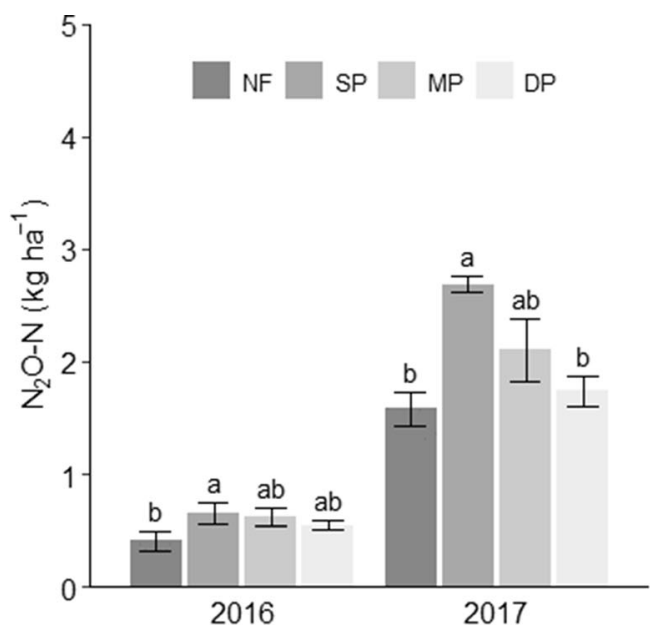

Fig. 2 Cumulative $\mathrm{N}_{2} \mathrm{O}\left(\mathrm{kg} \mathrm{N}_{2} \mathrm{O}-\mathrm{N} \mathrm{ha}^{-1}\right)$ and $\mathrm{CH}_{4}\left(\mathrm{~g} \mathrm{CH}_{4}-\mathrm{C}\right.$ $\mathrm{ha}^{-1}$ ) fluxes over the cropping seasons in 2016 and 2017. Vertical error bars represent standard error (SE) of the mean. Different letters highlight significant differences between the intermediates between that and NF and not significantly different from the other treatments.

During the more intense measuring period in 2017, average DP emissions were similar to those in NF, but signficantly lower than in SP. Emissions from MP and SP did not differ significantly. Among the fertilized treatments, $\mathrm{N}_{2} \mathrm{O}$ emissions were significantly the lowest in DP and MP and highest in SP on 8 out of 22 occasions in 2017, primarily in the first third of the cropping season (mid-May to early July) during a period of the most vigorous crop growth and minimal precipitation (Fig. 1, Table S1). The average value ( \pm SD) of measured $\mathrm{N}_{2} \mathrm{O}$ fluxes in 2017 was highest in SP and MP, $69.9 \pm 49.1$ and $56.9 \pm 52.9 \mu \mathrm{g} \mathrm{N} \mathrm{N}_{2} \mathrm{O}-\mathrm{N}$ $\mathrm{m}^{-2} \mathrm{~h}^{-1}$ respectively, and lowest in DP and NF, $44.9 \pm 39.2$ and $43.8 \pm 37.9 \mu \mathrm{g} \mathrm{N}_{2} \mathrm{O}-\mathrm{N} \mathrm{m}^{-2} \mathrm{~h}^{-1}$ respectively. Across all treatments, the lowest measured flux occurred early in the growing season, within either the first two days (SP and MP) or shortly after seed emergence (NF and DP), around 1.5 weeks of measurements, and the highest fluxes measured were on August 1st. Individual NF fluxes ranged from -18.9 to $210.9 \mu \mathrm{g} \mathrm{N}_{2} \mathrm{O}-\mathrm{N} \mathrm{m}^{-2} \mathrm{~h}^{-1}$ and were never statistically higher than the fertilized plots. The lowest and highest measured fluxes among all treatments during this period were in MP, -10.6 and $400.1 \mu \mathrm{g}$ $\mathrm{N}_{2} \mathrm{O}-\mathrm{N} \mathrm{m}^{-2} \mathrm{~h}^{-1}$ respectively. On 7 occasions, MP and SP were statistically highest but on a further 3 occasions MP was statistically lower than SP and

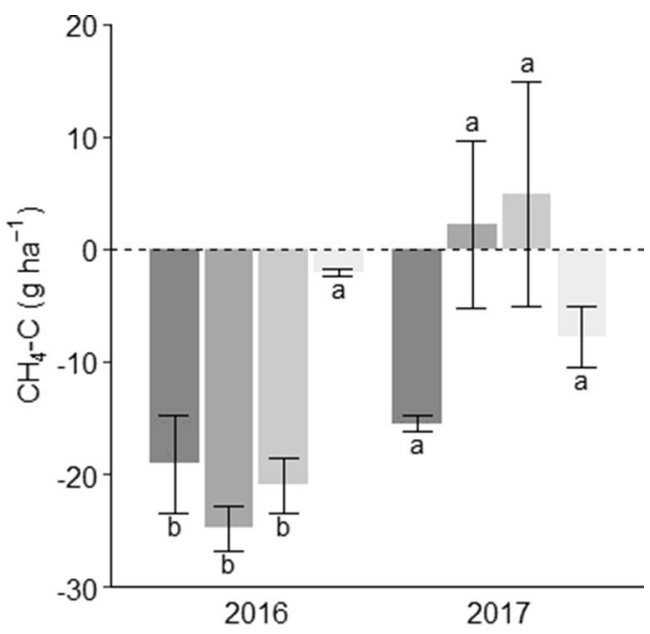

treatments in the respective year. NF $=$ no fertilizer, $\mathrm{SP}=$ shallow fertilizer placement $(0.07 \mathrm{~m}), \mathrm{MP}=$ mixed placement of fertilizer (half at $0.07 \mathrm{~m}$, half at $0.20 \mathrm{~m}$ ), and $\mathrm{DP}=$ deep fertilizer placement $(0.20 \mathrm{~m})$ 
either similar to DP or an intermediate between the two treatments (Table $\mathrm{S} 1$ ). Fluxes of $\mathrm{N}_{2} \mathrm{O}$ in $\mathrm{SP}$ ranged from 3.7 to $291.9 \mu \mathrm{g} \mathrm{N}_{2} \mathrm{O}-\mathrm{N} \mathrm{m}^{-2} \mathrm{~h}^{-1}$. Nitrous oxide fluxes in DP ranged from 0.8 to $174.9 \mu \mathrm{g} \mathrm{N} \mathrm{N}_{2} \mathrm{O}-\mathrm{N}$ $\mathrm{m}^{-2} \mathrm{~h}^{-1}$ (Table S1).

When crop season cumulative $\mathrm{N}_{2} \mathrm{O}$ emissions were yield-scaled (Fig. 3), a consistent trend emerged among treatments. Fertilizer depth significantly affected yield-scaled $\mathrm{N}_{2} \mathrm{O}$ emissions in 2017 where the GHG measurement period was longer. Yieldscaled $\mathrm{N}_{2} \mathrm{O}$ emissions were lowest in NF both years, 0.10 and $0.35 \mathrm{~g} \mathrm{~N}_{2} \mathrm{O}-\mathrm{N} \mathrm{kg}$ grain $^{-1}$ in 2016 and 2017, respectively. SP was highest in both $2016(0.15 \mathrm{~g}$ $\mathrm{N}_{2} \mathrm{O}-\mathrm{N} \mathrm{kg}$ grain $\left.^{-1}\right)$ and $2017\left(0.70 \mathrm{~g} \mathrm{~N}_{2} \mathrm{O}-\mathrm{N} \mathrm{kg}\right.$ grain $^{-1}$ ). Among the fertilized treatments, DP yieldscaled emissions were the lowest, 0.11 and $0.40 \mathrm{~g}$ $\mathrm{N}_{2} \mathrm{O}-\mathrm{N}$ per kg grain in 2016 and 2017, respectively, a reduction of 26 and $43 \%$ compared to SP. MP reduced yield-scaled emissions by $9 \%\left(0.14 \mathrm{~g} \mathrm{~N}_{2} \mathrm{O}-\mathrm{N} \mathrm{kg}\right.$ grain $\left.^{-1}\right)$ and $25 \%\left(0.52 \mathrm{~g} \mathrm{~N}_{2} \mathrm{O}-\mathrm{N} \mathrm{kg}\right.$ grain $\left.^{-1}\right)$ in 2016 and 2017 compared to SP. Fertilizer-induced emission factors (EF) calculated for the 2017 cropping season also decreased with depth of fertilizer placement. The percentage of applied $\mathrm{N}$ that was directly emitted as $\mathrm{N}_{2} \mathrm{O}$ for SP, MP, and DP was $0.77 \pm 0.07,0.58 \pm 0.03$, and $0.10 \pm 0.02$, repectively.

Cumulative $\mathrm{N}_{2} \mathrm{O}$ (Figure $\mathrm{S} 1$ ) and daily emissions (Figure S2) from the two-week spring thaw

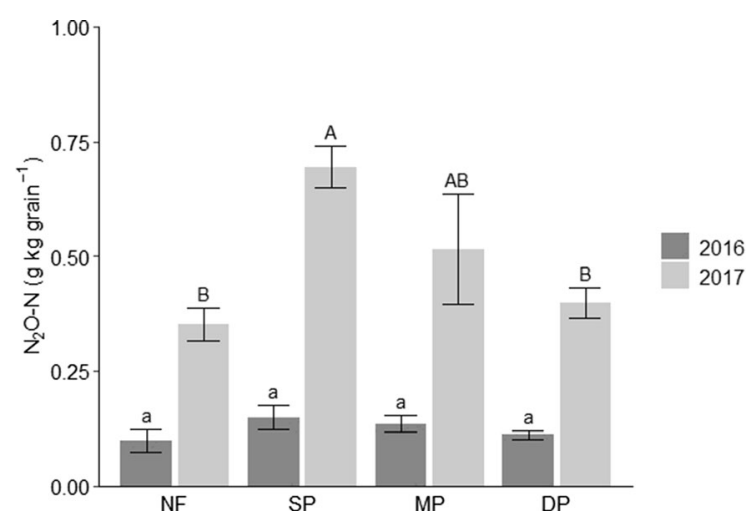

Fig. 3 Yield-scaled $\mathrm{N}_{2} \mathrm{O}$ emissions (cumulative $\mathrm{N}_{2} \mathrm{O}-\mathrm{N}$ g kg grain yield ${ }^{-1} \pm \mathrm{SE}$ ) per cropping year. Different small letters are significant treatment differences in 2016 and large letters represent significant treatment differences in 2017 ( $\alpha=0.05$, Tukey's HSD). Vertical error bars represent standard error (SE) of the mean. NF = no fertilizer, $\mathrm{SP}=$ shallow fertilizer placement $(0.07 \mathrm{~m}), \mathrm{MP}=$ mixed placement of fertilizer (half at $0.07 \mathrm{~m}$, half at $0.20 \mathrm{~m}$ ), and DP = deep fertilizer placement $(0.20 \mathrm{~m})$ measurement period in spring 2018 were no longer affected by fertilizer placement, but comprised between 40 and $70 \%$ of the cumulative emissions from the 2017 cropping season (see supplementary material). However, given the low number of observations, those results are less reliable. More frequent measurements over a longer period have to be made in order to make a concise statement about the impact of thaw conditions on $\mathrm{N}_{2} \mathrm{O}$ fluxes.

\section{Methane}

Methane fluxes were generally negative or very low in all treatments (Fig. 1). There was no statistical treatment differences in cumulative emissions in 2017 (Fig. 2) and a treatment effect was detected on only four different measurement occasions (Table S1), excluding the initial disturbance effect from planting and fertilization. The non-fertilized control had the highest uptake, with fluxes averaging ( \pm SD) $-5.5 \pm 19.1 \mu \mathrm{g} \mathrm{CH}_{4}-\mathrm{C} \mathrm{m}^{-2} \mathrm{~h}^{-1}$ and individual fluxes ranged from -76 to $33 \mu \mathrm{g} \mathrm{CH}_{4}-\mathrm{C} \mathrm{m}^{-2} \mathrm{~h}^{-1}$. The average $\mathrm{CH}_{4}$ flux in DP was $-3.9 \pm 13.1 \mu \mathrm{g}$ $\mathrm{CH}_{4}-\mathrm{C} \mathrm{m}^{-2} \mathrm{~h}^{-1}$ with highest and lowest measured fluxes -41.0 and $32.4 \mu \mathrm{g} \mathrm{CH}_{4}-\mathrm{C} \mathrm{m}^{-2} \mathrm{~h}^{-1}$, respectively. NF and DP were generally lower than both SP and MP on dates with significant treatment differences (Table S1). In 2017 SP and MP had the highest average $\mathrm{CH}_{4}$ emissions $( \pm \mathrm{SD}), \quad-1.7 \pm 16.3$ and $-2.0 \pm 20.0 \mu \mathrm{g} \mathrm{CH}_{4}-\mathrm{C} \mathrm{m}^{-2} \mathrm{~h}^{-1}$, respectively. MP minimum and maximum values were -92 and $57 \mu \mathrm{g}$ $\mathrm{CH}_{4}-\mathrm{C} \mathrm{m}^{-2} \mathrm{~h}^{-1}$. Minimum and maximum fluxes in SP were -38 and $43 \mu \mathrm{g} \mathrm{CH}_{4}-\mathrm{C} \mathrm{m}^{-2} \mathrm{~h}^{-1}$. Methane fluxes were significantly different among treatments in the latter part of the season, up to the final measurement in mid-September at the time of harvest (Table S1).

In the 2-week spring 2018 measurement period (Figure S2), no treatment differences were detected either cumulatively or on individual measurement dates (see supplementary material). However, there are too few observations from which to draw conclusions.

\section{Biomass and yield}

Fertilization increased $\mathrm{N}$ concentrations mid-season in the plant biomass and in harvested straw and grain for both growing seasons, observeable during mid-season 
SPAD readings, and after $\mathrm{N}$ analysis of collected biomass and harvested grain (Table 3). In 2016, there was no detectable treatment difference in SPAD values among fertilized plots, but mid-season biomass weight increased with fertilizer placement depth in the latter part of the growing season. Early plant height, an indication of accelerated maturation, when measured around the same time, was highest in NF $(0.69 \mathrm{~m})$, followed by SP and DP (0.67 and $0.66 \mathrm{~m}$, respectively), and was significantly lowest in MP (0.64). N content in the first mid-season biomass during elongation was highest in both MP and DP (2.42 and $2.48 \%$, respectively), but later biomass $\mathrm{N}$ fertilizer placement differences during heading were not observed. Additionally, in 2016, grain yield was increased by approximately $11 \%$ in DP compared to $\mathrm{SP}$, and grain $\mathrm{N}$ content also increased in both MP and DP. In 2017, despite higher mid-season SPAD

Table 3 Treatment effects on $\mathrm{N}$ concentration in crop biomass (dry matter) and harvested straw and grain, leaf relative chlorophyll content (SPAD-index), and harvest grain yield readings in DP and MP treatments compared to SP, no significant differences in grain yield or grain $\mathrm{N}$ content were observed among fertilized treatments in the second growing season.

Following the insignificant differences in 2017 grain yields and the higher yields in NF compared to the fertilized treatments, the agronomic efficiency $\mathrm{AE}_{\mathrm{N}}$ was negative for all fertilized treatments. However, due to the higher $\mathrm{N}$ contents in the grains and the straw in the fertilized treatments, the $\mathrm{N}$ recovery efficiency $R_{\mathrm{N}}$ was still low but above zero. They ranged from 2.3 in SP to $18.1 \%$ in DP (Table 4).

(15\% water content) at respective Zadok's growth stages in the 2016 and 2017 growing seasons

\begin{tabular}{|c|c|c|c|c|c|}
\hline & Zadok stage & $N F$ & $S P$ & $M P$ & $D P$ \\
\hline \multicolumn{6}{|l|}{2016} \\
\hline Biomass N (\%) & Elongation & $1.74 \pm 0.05^{\mathrm{c}}$ & $2.22 \pm 0.01^{\mathrm{b}}$ & $2.42 \pm 0.05^{\mathrm{a}}$ & $2.48 \pm 0.07^{\mathrm{a}}$ \\
\hline Biomass N (\%) & Heading & $1.25 \pm 0.05^{\mathrm{b}}$ & $1.63 \pm 0.03^{\mathrm{a}}$ & $1.66 \pm 0.04^{\mathrm{a}}$ & $1.52 \pm 0.05^{\mathrm{a}}$ \\
\hline Plant biomass $\left(\mathrm{t} \mathrm{ha}^{-1}\right)$ & Elongation & $4.06 \pm 0.14^{\mathrm{b}}$ & $4.81 \pm 0.20^{\mathrm{a}}$ & $4.64 \pm 0.10^{\mathrm{a}}$ & $4.88 \pm 0.13^{\mathrm{a}}$ \\
\hline Plant biomass $\left(\mathrm{t} \mathrm{ha}^{-1}\right)$ & Heading & $7.65 \pm 0.25^{\mathrm{b}}$ & $8.20 \pm 0.33^{\mathrm{ab}}$ & $8.44 \pm 0.22^{\mathrm{ab}}$ & $8.78 \pm 0.26^{\mathrm{a}}$ \\
\hline Plant height (m) & Elongation & $0.68 \pm 0.005^{\mathrm{a}}$ & $0.66 \pm 0.004^{\mathrm{b}}$ & $0.64 \pm 0.005^{\mathrm{c}}$ & $0.66 \pm 0.005^{\mathrm{b}}$ \\
\hline Plant height (m) & Heading & $0.70 \pm 0.005$ & $0.71 \pm 0.005$ & $0.70 \pm 0.005$ & $0.71 \pm 0.006$ \\
\hline SPAD-index & Elongation & $49.4 \pm 0.4^{\mathrm{b}}$ & $54.2 \pm 0.3^{\mathrm{a}}$ & $54.0 \pm 0.3^{\mathrm{a}}$ & $53.1 \pm 0.3^{\mathrm{a}}$ \\
\hline SPAD-index & Heading & $47.9 \pm 0.5^{\mathrm{b}}$ & $53.6 \pm 0.4^{\mathrm{a}}$ & $53.7 \pm 0.3^{\mathrm{a}}$ & $54.0 \pm 0.3^{\mathrm{a}}$ \\
\hline Straw N (\%) & Harvest & $0.23 \pm 0.02^{\mathrm{b}}$ & $0.31 \pm 0.01^{\mathrm{a}}$ & $0.33 \pm 0.02^{\mathrm{a}}$ & $0.33 \pm 0.02^{\mathrm{a}}$ \\
\hline Grain N (\%) & Harvest & $2.45 \pm 0.02^{\mathrm{c}}$ & $2.76 \pm 0.02^{\mathrm{b}}$ & $2.87 \pm 0.02^{\mathrm{a}}$ & $2.83 \pm 0.02^{\mathrm{a}}$ \\
\hline Grain yield $\left(\mathrm{kg} \mathrm{ha}^{-1}\right)$ & Harvest & $4.18 \pm 0.06^{\mathrm{c}}$ & $4.40 \pm 0.12^{\mathrm{bc}}$ & $4.62 \pm 0.09^{\mathrm{ab}}$ & $4.88 \pm 0.1^{\mathrm{a}}$ \\
\hline \multicolumn{6}{|l|}{2017} \\
\hline Biomass N (\%) & Booting & $1.49 \pm 0.04$ & $1.87 \pm 0.06$ & $1.87 \pm 0.05$ & $1.87 \pm 0.03$ \\
\hline Plant biomass $\left(\mathrm{t} \mathrm{ha}^{-1}\right)$ & Booting & $5.05 \pm 0.32$ & $5.21 \pm 0.31$ & $5.74 \pm 0.38$ & $5.66 \pm 0.25$ \\
\hline Plant height (m) & Booting & $0.65 \pm 0.008^{\mathrm{b}}$ & $0.63 \pm 0.007^{\mathrm{b}}$ & $0.66 \pm 0.008^{\mathrm{ab}}$ & $0.69 \pm 0.008^{\mathrm{a}}$ \\
\hline SPAD-index & Booting & $57.6 \pm 0.6^{\mathrm{b}}$ & $59.1 \pm 0.5^{\mathrm{b}}$ & $60.1 \pm 0.6^{\mathrm{a}}$ & $59.7 \pm 0.5^{\mathrm{a}}$ \\
\hline Straw N (\%) & Harvest & $0.52 \pm 0.01^{\mathrm{b}}$ & $0.73 \pm 0.03^{\mathrm{a}}$ & $0.72 \pm 0.03^{\mathrm{a}}$ & $0.68 \pm 0.04^{\mathrm{a}}$ \\
\hline Grain N (\%) & Harvest & $2.11 \pm 0.02^{\mathrm{b}}$ & $2.41 \pm 0.03^{\mathrm{a}}$ & $2.43 \pm 0.02^{\mathrm{a}}$ & $2.40 \pm 0.02^{\mathrm{a}}$ \\
\hline Grain yield $\left(\mathrm{kg} \mathrm{ha}^{-1}\right)$ & Harvest & $4.49 \pm 0.12^{\mathrm{a}}$ & $3.87 \pm 0.16^{\mathrm{a}}$ & $4.08 \pm 0.28^{\mathrm{a}}$ & $4.36 \pm 0.12^{\mathrm{a}}$ \\
\hline
\end{tabular}

Values are reported as means \pm standard errors. Different letters indicate statistical difference $(\alpha=0.05$, Tukey's HSD)

$\mathrm{NF}=$ no fertilizer, $\mathrm{SP}=$ shallow fertilizer placement $(0.07 \mathrm{~m}), \mathrm{MP}=\operatorname{mixed}$ placement of fertilizer $($ half at $0.07 \mathrm{~m}$, half at $0.20 \mathrm{~m})$, and DP = deep fertilizer placement $(0.20 \mathrm{~m})$ 
Table 4 Nitrogen balance components in the four experimental treatments for the 2017 cropping season

\begin{tabular}{|c|c|c|c|c|}
\hline & $\mathrm{NF}$ & SP & MP & DP \\
\hline \multicolumn{5}{|l|}{$N$ inputs and outputs $\left(\mathrm{kg} \mathrm{N}^{-1}\right)$} \\
\hline Seeds & 5.3 & 5.3 & 5.3 & 5.3 \\
\hline Fertilization & 0 & 105 & 105 & 105 \\
\hline Harvested grains & $-101.1 \pm 9.2$ & $-97.0 \pm 8.1$ & $-104.4 \pm 14.9$ & $-111.1 \pm 4.8$ \\
\hline Harvested straw & $-21.1 \pm 3.3$ & $-27.5 \pm 3.3$ & $-30.5 \pm 2.8$ & $-30 \pm 2.9$ \\
\hline $\mathrm{N}_{2} \mathrm{O}$ loss & $-1.6 \pm 0.1$ & $-2.7 \pm 0.1$ & $-2.1 \pm 0.3$ & $-1.7 \pm 0.1$ \\
\hline$N$ surplus & $-118.5 \pm 5.4$ & $-16.9 \pm 4.5$ & $-26.7 \pm 6.8$ & $-32.5 \pm 3.2$ \\
\hline $\operatorname{NUE}(\%)$ & n.a. & 119 & 128 & 134 \\
\hline $\mathrm{AE}_{\mathrm{N}}\left(\mathrm{kg} \mathrm{ha}^{-1}\right)$ & n.a. & -5.9 & -3.9 & -1.2 \\
\hline $\mathrm{RE}_{\mathrm{N}}(\%)$ & n.a. & 2.3 & 12.2 & 18.1 \\
\hline \multicolumn{5}{|c|}{ 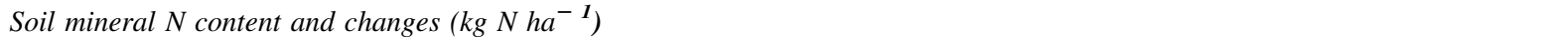 } \\
\hline Soil mineral $\mathrm{N}$ at sowing $(0-0.25 \mathrm{~m})$ & $37.4 \pm 2.3$ & $42.6 \pm 0.9$ & $42.4 \pm 2.7$ & $36.8 \pm 3.9$ \\
\hline Soil mineral $\mathrm{N}$ at sowing $(0.25-0.40 \mathrm{~m})$ & $22.1 \pm 1.6$ & $30.5 \pm 1.8$ & $37.4 \pm 6.5$ & $34.0 \pm 4.2$ \\
\hline Soil mineral $\mathrm{N}$ after harvest $(0-0.25 \mathrm{~m})$ & $25.0 \pm 3.0$ & $82.7 \pm 17.1$ & $54.0 \pm 7.8$ & $42.2 \pm 1.6$ \\
\hline Soil mineral $\mathrm{N}$ after harvest $(0.25-0.40 \mathrm{~m})$ & $16.6 \pm 2.6$ & $31.6 \pm 0.7$ & $47.6 \pm 20.5$ & $37.3 \pm 2.5$ \\
\hline$\Delta$ Soil mineral $\mathrm{N}(0-0.25 \mathrm{~m})$ & $-15.7 \pm 6.2$ & $40.4 \pm 16.5$ & $6.9 \pm 10.0$ & $-1.9 \pm 2.3$ \\
\hline$\Delta$ Soil mineral $\mathrm{N}(0.25-0.40 \mathrm{~m})$ & $-8.6 \pm 3.4$ & $-1.7 \pm 2.7$ & $-0.7 \pm 26.0$ & $-4.8 \pm 2.2$ \\
\hline Total increase in mineral $\mathrm{N}(0-0.40 \mathrm{~m})$ & $-24.3 \pm 9.6$ & $38.7 \pm 13.9$ & $6.2 \pm 36.0$ & $-6.6 \pm 4.7$ \\
\hline
\end{tabular}

The change in soil mineral $\mathrm{N}$ content was calculated from subtracting mineral $\mathrm{N}$ content measured one week before fertilization (at sowing) from soil mineral $\mathrm{N}$ content measured one week after harvest. Values are presented as mean \pm standard error

$\mathrm{NF}=$ no fertilizer, $\mathrm{SP}=$ shallow fertilizer placement $(0.07 \mathrm{~m}), \mathrm{MP}=$ mixed placement of fertilizer $($ half at $0.07 \mathrm{~m}$, half at $0.20 \mathrm{~m})$, and $\mathrm{DP}=$ deep fertilizer placement $(0.20 \mathrm{~m}) . \mathrm{NUE}=\mathrm{N}$ use efficiency, $\mathrm{AE}_{\mathrm{N}}=$ agronomic efficiency of $\mathrm{N}, \mathrm{RE}_{\mathrm{N}}=$ recovery efficiency of $\mathrm{N}$

Soil mineral $\mathrm{N}$ profiles and $\mathrm{N}$ balance

Data from the 2017 soil mineral $\mathrm{N}$ profile measurements (Fig. 4) and resulting $\mathrm{N}$ balance (Table 4) indicate that mineral $\mathrm{N}$ content had decreased in the $0.25-0.40 \mathrm{~m}$ layer in all treatments (Table 4). For NF and DP, mineral $\mathrm{N}$ had even disappeared from the 0-25 cm layer during the growing season. SP resulted in a higher surplus of mineral $\mathrm{N}$ remaining in the system after harvest than in the other treatments $\left(38.7 \pm 13.9 \mathrm{~kg} \mathrm{~N} \mathrm{ha}^{-1}\right)$. The mineral $\mathrm{N}$ content in the mid-crop season soil profile pinpoint more or less where the fertilizer grains had been placed; SP, which was placed at $0.07 \mathrm{~m}$ depth, was primarily found between 0.05 and $0.10 \mathrm{~m}$. After harvest, it appears that the bulk of SP soil mineral $\mathrm{N}$ essentially remained in the soil, but had leached further down in the profile to $0.25 \mathrm{~m}$. However, in the $0.25-0.40 \mathrm{~m}$ layer, mineral $\mathrm{N}$ content had decreased by $1.7 \pm 2.7 \mathrm{~kg} \mathrm{~N} \mathrm{ha}^{-1}$. The MP treatment had its largest mid-season $\mathrm{N}$ content peak at $0.10 \mathrm{~m}$, with a gradual decline in soil $\mathrm{N}$ content from 0.10 to $0.25 \mathrm{~m}$. After crop harvest, the $0.10 \mathrm{~m} \mathrm{~N}$ content peak of MP had nearly halved, and another distinct $\mathrm{N}$ content peak was observed deeper in the soil profile at $0.40 \mathrm{~m}$. Only a small fraction of the negative $\mathrm{N}$ surplus of $118.5 \mathrm{~kg}$ in the unfertilized control was explained by the decrease in soil mineral $\mathrm{N}\left(6.2 \pm 36.0 \mathrm{~kg} \mathrm{~N} \mathrm{ha}^{-1}\right)$ during the cropping season. Thus net $\mathrm{N}$ mineralization during the growing season would have been at least $100 \mathrm{~kg} \mathrm{~N}$ explaining the weak fertilizer response of crop yield in the fertilized treatments (Table 4). Less soil mineral $\mathrm{N}$ was detected in DP after harvest than in the other fertilized treatments and more $\mathrm{N}$ was removed from the system through harvested straw and grains resulting in a higher nutrient use efficiency of the applied fertilizer $\mathrm{N}$ and a higher uptake of mineral N (Table 4). Similar to NF, mineral $\mathrm{N}$ in the $0-0.40$ m layer decreased over the growing season. 

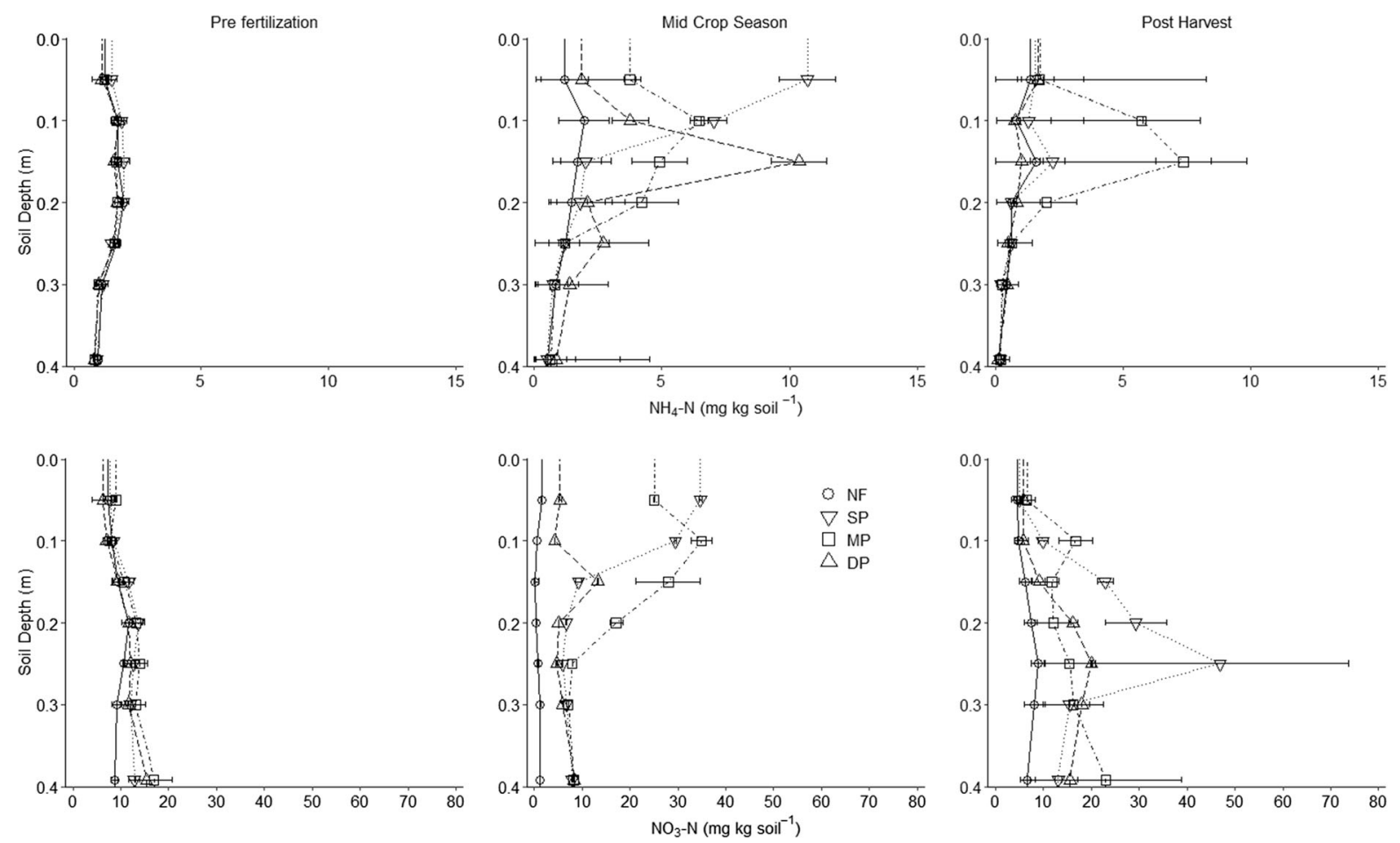

Fig. 4 Soil mineral $\mathrm{N}$ content $\left(\mathrm{mg} \mathrm{NO}_{3}-\mathrm{N}\right.$ and $\mathrm{NH}_{4}-\mathrm{N} \mathrm{kg}$ soil $^{-1}$ ) sampled in 2017 in $0.05 \mathrm{~m}$ increments to a $0.30 \mathrm{~m}$ depth and at $0.30-0.40 \mathrm{~m}$ depth. Treatment depth averages at five days prior to fertilization and sowing, two months after fertilization and sowing, and one week after harvest. Horizontal bars

\section{Discussion}

Effect of $\mathrm{N}$ placement on $\mathrm{N}_{2} \mathrm{O}$ emissions

Different depth placement of $\mathrm{N}$ fertilizer had a marked effect on $\mathrm{N}_{2} \mathrm{O}$ emissions. The reduction in $\mathrm{N}_{2} \mathrm{O}$ emissions from the DP treatment compared to both MP and SP was consistent with previous studies pointing out the connection between residence time of $\mathrm{N}_{2} \mathrm{O}$ in soil and uptake or reduction in the emission of $\mathrm{N}_{2} \mathrm{O}$ (Clough et al. 1998; Harter et al. 2016). Nitrous oxide emissions from DP were generally as low as those from the unfertilized plots, a trend consistent during both the abbreviated cumulative measurement period of 2016, and for both cumulative and individual measurements in 2017. We had expected that MP, which received half the amount of fertilizer at the same depth as SP to be an intermediate between the highest and lowest emitters, but that was not always the case. During both cropping seasons, the $\mathrm{N}_{2} \mathrm{O}$ emissions from MP plots were generally as high as represent \pm standard error $(\mathrm{SE})$ of the mean. $\mathrm{NF}=$ no fertilizer, $\mathrm{SP}=$ shallow fertilizer placement $(0.07 \mathrm{~m}), \mathrm{MP}=$ mixed placement of fertilizer (half at $0.07 \mathrm{~m}$, half at $0.20 \mathrm{~m}$ ), and DP = deep fertilizer placement $(0.20 \mathrm{~m})$

those from SP, consistent with findings of ChapuisLardy et al. (2007). The higher concentration of mineral $\mathrm{N}$ in the upper topsoil of MP (Fig. 4) could explain why no significant reduction was achieved. Compared with SP, DP reduced cumulative $\mathrm{N}_{2} \mathrm{O}$ emissions by $18 \%$ and $35 \%$ during the GHG measurement periods during the first and second growing seasons, respectively. The fertilizer-induced $\mathrm{N}_{2} \mathrm{O}$ emissions decreased with placement depth and the calculated emission factors for SP, MP, and DP were $0.77 \pm 0.07,0.58 \pm 0.03$, and $0.10 \pm 0.02$, respectively. Similar to our findings, van Kessel et al. (2013) found in a metanalysis that $\mathrm{N}_{2} \mathrm{O}$ emissions were reduced when $\mathrm{N}$ fertilizers were placed at a depth $\geq 0.05 \mathrm{~m}$. Moreover, they reported that deep fertilizer placement significantly reduced yield-scaled emissions in no tillage and reduced tillage systems in humid climates. This is similar to our findings, where yield-scaled emissions were lower from deep (DP) than from shallow (SP) placement. Gaihre et al. (2015) found that urea deep placement $(0.07-0.10 \mathrm{~m}$ depth 
placement) reduced $\mathrm{N}_{2} \mathrm{O}$ emissions by up to $84 \%$ compared to surface broadcast application during the dry season and also increased rice grain yields by $13 \%$ in one season and gave similar yields in another season, despite a lower $\mathrm{N}$ application (Gaihre et al. 2018).

Generally, treatment differences were first detectable several weeks after fertilization. The strongest significant treatment effects on $\mathrm{N}_{2} \mathrm{O}$ formation and emissions were recorded during the 3 rd -5 th week after sowing and fertilization, i.e., in the first third of the 2017 growing season. It can be assumed that vigorous plant growth and $\mathrm{N}$ uptake from soil influenced the decreased $\mathrm{N}_{2} \mathrm{O}$ emissions in DP, but not MP, which still had high $\mathrm{N}_{2} \mathrm{O}$ emissions.

The treatment effect on $\mathrm{N}_{2} \mathrm{O}$ emissions largely disappeared during the latter two-thirds of the 2017 growing season (Fig. 1). This was during a time when chamber measurements were less frequent, so it is possible that some emission peaks and thus treatment effects were missed. On the other hand, in the final weeks of the 2017 growing season, $\mathrm{N}_{2} \mathrm{O}$ fluxes from fertilized and non-fertilized plots were similar, showing that neither fertilizer depth placement nor crop utilization were important drivers for $\mathrm{N}_{2} \mathrm{O}$ emissions at this stage when mineral $\mathrm{N}$ was largely utilized or had been translocated to a lower soil depth (Fig. 4). This assumption is somewhat supported by the higher WFPS observed towards the end of the experiment (41\% in late August and $66 \%$ in mid-September). Apart from that, WFPS was rather low $(25 \%$ on average) throughout the whole growing season in 2017. This leads to the assumption that nitrification rather than denitrification has been the major process of $\mathrm{N}_{2} \mathrm{O}$ production. However, based on the data observed in this study, we did not find a correlation between $\mathrm{N}_{2} \mathrm{O}$ emissions and WFPS in either of the years.

\section{Effect of $\mathrm{N}$ placement on $\mathrm{CH}_{4}$ emissions}

Methane fluxes in 2017 were generally low and negative in all treatments with little differences between DP and NF. Moreover, there was lower $\mathrm{CH}_{4}$ oxidation and consequently higher positive fluxes in the MP and SP treatment (Fig. 2). This is consistent with previous findings that have linked surface and shallow fertilizer $\mathrm{N}$ application to higher $\mathrm{CH}_{4}$ fluxes (Bodelier 2011) as most $\mathrm{CH}_{4}$ oxidation occurs in the upper (0-0.05 m) soil layer (Crill et al. 1994; Kruger et al. 2001). For rice fields, Linquist et al. (2012) reported reduced $\mathrm{CH}_{4}$ emissions from urea deep placement as compared to broadcast application. The studies included in their meta-analysis mostly reported lower $\mathrm{CH}_{4}$ emissions when $\mathrm{N}$ fertilizer was placed below the soil surface in continuous (Schutz et al. 1989), rainfed (Rath et al. 1999) and irrigated (Setyanto et al. 2000) water management. However, when comparing irrigated and rainfed rice systems, Setyanto et al. (2000) reported higher $\mathrm{CH}_{4}$ emissions from the deep $\mathrm{N}$ placement under rainfed conditions. In general, a decreasing effect of deep $\mathrm{N}$ placement has been related to concentrated $\mathrm{NH}_{4}{ }^{+}$into localized areas, as well as increased $\mathrm{O}_{2}$ availability in the rhizosphere, thus stimulating $\mathrm{CH}_{4}$ oxidation and reducing overall emissions (Bodelier et al. 2000a, b; Gilbert and Frenzel 1998). By contrast, results from studies focussing on fertilizer placement revealed that $\mathrm{N}$ placement has no effect on $\mathrm{CH}_{4}$ emissions in irrigated rice systems (Adviento-Borbe and Linquist 2016; Yao et al. 2017), upland soil under corn (Liu et al. 2006), or winter barley (Chu et al. 2007). In the study presented here, observed WFPS was comparatively low throughout the growing seasons, indicating that the soil water regime was the major driver of the low $\mathrm{CH}_{4}$ emissions observed. Aside from the differences in the water regimes between the abovementioned studies on rice cultivation and the results presented here, the definition of what is considered a deep placement is quite relative and varies between studies. For example, Schutz et al. (1989) and Yao et al. (2017) studied a placement depth of 0.20 and $0.10-0.15 \mathrm{~m}$, respectively, which is comparable to the DP treament presented in this study. By contrast, Rath et al. (1999) considered $0.05 \mathrm{~m}$ to be a deep placement, which is analogous to our SP treatment.

Biomass, $\mathrm{N}$ balance, and soil mineral $\mathrm{N}$

Both cropping seasons had less than normal rainfall during the former part of the growing season (Table 1), which was a possible culprit for generally lower than normal yields. Spring wheat grain yield was $4.18-4.88 \mathrm{tha}^{-1}$ in 2016 and spring barley grain yield was 3.87-4.49 $\mathrm{t} \mathrm{ha}^{-1}$ in 2017 (Table 3). In comparison, the average yield in Uppsala county for spring wheat in 2016 was 4.49 tons ha ${ }^{-1}$, and barley in 2017 was $5.07 \mathrm{t} \mathrm{ha}^{-1}$ (Jordbruksverket 2017, 2018). 
However, in 2016, nearly half of the field had been overtaken by weeds halfway through the growing season. In 2017, the uneven and delayed seed emergence from shallow seed placement resulted in differing rates of plant maturation that ultimately led to high variation in both yields and average nutrient uptake in all treatments. Despite poor growth and high variation across all plots in 2017, an increase in NUE with deeper fertilizer placement was clear (Table 4) and DP fertilization had a positive effect on yield (Table 3) compared to the other fertilized treatments, and overall improved the grain $\mathrm{N}$ content. In general, the high values for NUE suggest a high susceptibility to mining of $\mathrm{N}$, i.e. $\mathrm{N}$ depletion and soil $\mathrm{C}$ degradation (Quemada et al. 2020). According to the EU Nitrogen Expert Panel (EUNEP 2015), the desirable NUE range is $50-90 \%$. In our study, calculated NUEs in 2017 were 119 (SP), 128 (MP) and 134\% (DP), which is above the range presented by Quemada et al. (2020) for arable farms in Denmark, Germany, and Spain. $50 \%$ of the farms included in their analysis had NUE values between 45 and $75 \%$. For rice cultivation, deep placement of fertilizer has been found to significantly increase both NUE and grain yield, as well as agronomical $\mathrm{N}$ efficiency and $\mathrm{N}$ recovery efficiency (Das and Singh 1994; Xiang et al. 2013; Bandaogo et al. 2014; Huda et al. 2016). For flooded rice, Huda et al. (2016) reported similar floodwater $\mathrm{NH}_{4}{ }^{+}-\mathrm{N}$ and ammonia $\left(\mathrm{NH}_{3}\right)$ volatilization in deep-placed treatments and unfertilized control. Using controlledrelease $\mathrm{N}$ fertilizers in two consecutive rice growing seasons, Ke et al. (2018) found that fertilizer deep placement increased $\mathrm{N}$ leaching and the mineral $\mathrm{N}$ in the $0.40-0.60 \mathrm{~m}$ soil layer. However, in their study, the fertilizer was placed at a depth of $0.05 \mathrm{~m}$ in the deep placement, which is even more shallow than the shallow placement (SP, $0.07 \mathrm{~m}$ ) applied in our experiment. In the study presented here, the soil-crop $\mathrm{N}$ balance (Table 4) was greatly influenced by remaining soil mineral N (Fig. 4), primarily in the form of $\mathrm{NO}_{3}{ }^{-}$, at the time of harvest. Interestingly, amounts of mineral $\mathrm{N}$ at harvest were 45 and $12 \mathrm{~kg} \mathrm{ha}^{-1}$ lower in DP than in SP and MP, respectively. These differences, 6 and $17 \mathrm{~kg} \mathrm{ha}^{-1}$ respectively, are partially explained by higher crop $\mathrm{N}$ uptake in DP, but the fate of the remaining $\mathrm{N}$ was unresolved (Table 4). Among the fertilized treatments in our study, SP showed the highest increase in mineral $\mathrm{N}$ in the whole $0-0.40 \mathrm{~m}$ depth $\left(38.7 \pm 13.9 \mathrm{~kg} \mathrm{~N} \mathrm{ha}^{-1}\right)$, which encompass an increase in $0-0.25 \mathrm{~m}$ depth (40.4 $\pm 16.5 \mathrm{~kg} \mathrm{~N} \mathrm{ha}^{-1}$ ), where it is susceptible to gaseous $\mathrm{N}$ losses, and a slight decrease in $0.25-0.40 \mathrm{~m}$ depth $\left(-1.7 \pm 2.7 \mathrm{~kg} \mathrm{~N} \mathrm{ha}^{-1}\right)$. Similarly, the mineral $\mathrm{N}$ increased in the MP treatment, in which the fertilizer was placed at 0.07 and $0.20 \mathrm{~m}$, at $0-0.25 \mathrm{~m}$ $\left(6.9 \pm 10.0 \mathrm{~kg} \mathrm{ha}^{-1}\right)$ and decreased in $0.25-0.40 \mathrm{~m}$ depth $\left(-0.7 \pm 26.0 \mathrm{~kg} \mathrm{ha}^{-1}\right)$, highlighting that $\mathrm{N}$ probably has leached further down the soil profile. Similar to NF, mineral $\mathrm{N}$ decreased in DP $\left(-6.6 \pm 4.7 \mathrm{~kg} \mathrm{ha}^{-1}\right)$, which may be explained by the higher $\mathrm{N}$ uptake and, consequently, yield (Table 4).

Ke et al. (2018) moreover reported an increase in $\mathrm{RE}_{\mathrm{N}}$ under the deep placement treatment compared to the broadcast application. Considering the grain yield, the positive impact of fertilizer deep placement depended on the fertilizer type and significantly higher grain yields were found for sulphur-coated urea, but not when polymer-coated urea was used. Similarly, Guo et al. (2016) found that deep placement of controlled-release fertilizer has the potential to increase $\mathrm{N}$ uptake and NUE in maize cultivation.

In the study presented here, the $\mathrm{N}$ fertilizer rate was designed for higher yields than those obtained in 2017. The fact that harvested grain yield was highest under the control treatment suggested that $\mathrm{N}$ fertilization was not needed in 2017 or even counterproductive as shown by the high values for NUE and the negative values for $\mathrm{AE}_{\mathrm{N}}$, which indicate that application of exogenous $\mathrm{N}$ did not lead to an increase in yield (Table 4). In contrast to 2017, values for $\mathrm{AE}_{\mathrm{N}}$ were positive in 2016. However, they were still rather low and between 1.8 for $\mathrm{SP}$ and $5.8 \mathrm{~kg}_{\text {grain }} \mathrm{kg}^{-1}$ applied $\mathrm{N}$ for DP. According to Dobermann (2005), common values for $A E_{N}$ are $10-30 \mathrm{~kg}$ grain $\mathrm{kg}^{-1}$ applied $\mathrm{N}$, with higher values in well-managed systems or at low $\mathrm{N}$ levels. For Europe, Lahda et al. (2005) reported an average $\mathrm{AE}_{\mathrm{N}}$ of $21.3 \mathrm{~kg}$ grain increase per $\mathrm{kg} \mathrm{N}$ applied, given a similar average fertilization rate as used in this study in $2017\left(100 \pm 13.9 \mathrm{~kg} \mathrm{ha}^{-1}\right)$.

In contrast to $\mathrm{AE}_{\mathrm{N}}$, the positive 2017 values for $\mathrm{RE}_{\mathrm{N}}$ (2.3, 12.2 and $18.1 \%$ for SP, MP and DP, respectively) indicate that, despite the very low yield, the plants were capable of aquiring the additional $\mathrm{N}$ in the grains and the straw. However, the obtained values for $\mathrm{RE}_{\mathrm{N}}$ are much lower than common values summarized by Dobermann (2005), which range between 30 and $50 \%$, with up to $80 \%$ achieved in 
well-managed systems. Compared to $\mathrm{RE}_{\mathrm{N}}$ values for cereals, as summarized by Lahda et al. (2005), i.e. 10 and $70 \%$, the efficiencies of the MP and DP treatment were at the lower range of this interval.

The positive impact of deep-placed fertilizer on $\mathrm{N}$ uptake and $\mathrm{N}$ efficiencies is strongly related to the higher soil moisture in deeper layers. The occurence of favorable nutrient and soil mositure conditions, which are expected to stimulate root proliferation, is more probable in deeper layers. Therefore, deep placement has been shown to be a successful management strategy to reach this aim (Li et al. 2009). However, the adoption of this practice might involve additional labor and costs in terms of purchasing suitable equipment for placing the fertilizer at the correct depth, as well as increased fuel consumption as compared to broadcast application.

\section{Conclusions}

Increasing the fertilizer $\mathrm{N}$ placement depth has the potential to both improve crop $\mathrm{N}$ content and yield, but also mitigate fertilizer-induced $\mathrm{N}_{2} \mathrm{O}$ emissions, and to a smaller extent, increase methane oxidation. The GHG mitigation effect of deeper fertilizer placement was first detectable several weeks after fertilization. Deep-placed fertilizer $\mathrm{N}$ did not appear to have been exposed to a greater downward mobility likely because of smaller changes in soil moisture following precipitation at this depth. The benefits of increased depth placement of $\mathrm{N}$ are likely dependent on climate and soil type but could be a further step in precision farming and environmentally sustainable agriculture. However, further investigations are needed before deeper placement of fertilizer can be recommended as a sustainable farming practice as indicated by our study.

Acknowledgements This work was funded by FORMAS, the Swedish government research council for sustainable development, Grant \# 229-2013-82. The authors would like to thank Elisabet Börjesson, Caroline Wright, Tsion Gizachew Tarekegn and Meseret Menil Abitew, Lisa Embring, Hannes Keck, Hannes Kätterer, Martin Hallinger, and Dan Johansson for their help in the field, as well as to Jan Fiedler for assistance in both the field and the GC lab, and Sabine Jordan and Abraham Joel for lending equipment. We also thank the anonymous reviewers for valuable comments to previous versions of this article.
Open Access This article is licensed under a Creative Commons Attribution 4.0 International License, which permits use, sharing, adaptation, distribution and reproduction in any medium or format, as long as you give appropriate credit to the original author(s) and the source, provide a link to the Creative Commons licence, and indicate if changes were made. The images or other third party material in this article are included in the article's Creative Commons licence, unless indicated otherwise in a credit line to the material. If material is not included in the article's Creative Commons licence and your intended use is not permitted by statutory regulation or exceeds the permitted use, you will need to obtain permission directly from the copyright holder. To view a copy of this licence, visit http://creativecommons.org/licenses/by/4.0/.

Funding Open access funding provided by Swedish University of Agricultural Sciences.

\section{References}

Adviento-Borbe MA, Linquist B (2016) Assessing fertilizer N placement on $\mathrm{CH}_{4}$ and $\mathrm{N}_{2} \mathrm{O}$ emissions in irrigated rice systems. Geoderma 266:40-45. https://doi.org/10.1016/j. geoderma.2015.11.034

Bandaogo A, Bidjokazo F, Youl S, Safo E, Abaidoo R, Andrews O (2014) Effect of fertilizer deep placement with urea supergranule on nitrogen use efficiency of irrigated rice in Sourou Valley (Burkina Faso). Nutr Cycl Agroecosyst 102:79-89. https://doi.org/10.1007/s10705-014-9653-6

Bodelier PLE, Hahn AP, Arth IR, Frenzel P (2000a) Effects of ammonium-based fertilisation on microbial processes involved in methane emission from soils planted with rice. Biogeochemistry 51:225-257. https://doi.org/10.1023/A: 1006438802362

Bodelier PLE, Roslev P, Henckel T, Frenzel P (2000b) Stimulation by ammonium based fertilisers of methane oxidation in soil around rice roots. Nature 43:421-424. https://doi. org/10.1038/35000193

Bodelier PLE (2011) Interactions between nitrogenous fertilizers and methane cycling in wetland and upland soils. Curr Opin Environ Sustain 3:379-388. https://doi.org/10.1016/ j.cosust.2011.06.002

Cai G, Chen D, White RE, Fan XH, Pacholski A, Zhu ZL, Ding $H$ (2002) Gaseous nitrogen losses from urea applied to maize on a calcareous fluvo-aquic soil in the North China Plain. Aust J Soil Res 40:737-748. https://doi.org/10.1071/ $\mathrm{Sr} 01011$

Cameron KC, Di HJ, Moir JL (2013) Nitrogen losses from the soil/plant system: a review. Ann Appl Biol 162:145-173. https://doi.org/10.1111/aab.12014

Chapuis-Lardy L, Wrage N, Metay A, Chotte J-L, Bernoux M (2007) Soils, a sink for $\mathrm{N}_{2} \mathrm{O}$ ? A review. Global Change Biol 13:1-17. https://doi.org/10.1111/j.1365-2486.2006. 01280.x

Chu HY, Hosen Y, Yagi K (2007) NO, $\mathrm{N}_{2} \mathrm{O}, \mathrm{CH}_{4}$ and $\mathrm{CO}_{2}$ fluxes in winter barley field of Japanese Andisol as affected 
by $\mathrm{N}$ fertilizer management. Soil Biol Biochem 39:330-339. https://doi.org/10.1016/j.soilbio.2006.08.003

Clough TJ, Jarvis SC, Dixon ER, Stevens RJ, Laughlin RJ, Hatch DJ (1998) Carbon induced subsoil denitrification of ${ }^{15} \mathrm{~N}$-labelled nitrate in $1 \mathrm{~m}$ deep soil columns. Soil Biol Biochem 31:31-41. https://doi.org/10.1016/s00380717(98)00097-2

Crill PM, Martikainen PJ, Nykänen H, Silvola J (1994) Temperature and $\mathrm{N}$ fertilization effects on methane oxidation in a drained peatland soil. Soil Biol Biochem 26:1331-1339. https://doi.org/10.1016/0038-0717(94)90214-3

Das S, Singh TA (1994) Nitrogen use efficiency by rice and flood water parameters as affected by fertilizer placement techniques. J Indian Soc Soil Sci 42(1):46-50

Dobermann AR (2005) Nitrogen Use Efficiency - State of the Art. IFA International Workshop on Enhanced-Efficiency Fertilizers. Frankfurt, Germany, 28-30 June 2005

Drury CF, Reynolds WD, Tan CS, Welacky TW, Calder W, McLaughlin NB (2006) Emissions of Nitrous Oxide and Carbon Dioxide. Soil Sci Soc Am J 70:570-581. https:// doi.org/10.2136/sssaj2005.0042

EUNEP (2015) Nitrogen Use Efficiency (NUE) - an indicator for the utilization of nitrogen in food systems. Wageningen University, Netherlands. http://eunep.com/wp-content/ uploads/2017/03/N-ExpertPanel-NUE-Session-1.pdf

Fox J, Weisberg S (2019) An R companion to applied regression, 3rd edn. Sage, Thousand Oaks

Fuss R (2019) gasfluxes: greenhouse gas flux calculation from chamber measurements. R package version 0.4-2. https:// CRAN.R-project.org/package= gasfluxes

Gaihre YK, Singh U, Islam SMM et al (2015) Impacts of urea deep placement on nitrous oxide and nitric oxide emissions from rice fields in Bangladesh. Geoderma 259-260:370-379. https://doi.org/10.1016/j.geoderma. 2015.06.001

Gaihre YK, Singh U, Islam SMM et al (2018) Nitrous oxide and nitric oxide emissions and nitrogen use efficiency as affected by nitrogen placement in lowland rice fields. Nutr Cycl Agroecosyst 110:277. https://doi.org/10.1007/ s10705-017-9897-z

Gilbert B, Frenzel P (1998) Rice roots and CH4 oxidation: the activity of bacteria, their distribution and the microenvironment. Soil Biol Biochem 30:1903-1916. https://doi. org/10.1016/S0038-0717(98)00061-3

Godde M, Conrad R (1999) Immediate and adaptational temperature effects on nitric oxide production and nitrous oxide release from nitrification and denitrification in two soils. Biol Fertil Soil 30:33-40. https://doi.org/10.1007/ s003740050584

Grant K, Macrae ML, Rezanezhad F, Vito Lam W (2019) Nutrient leaching in soil affected by fertilizer application and frozen ground. Vadose Zone J 18:180150. https://doi. org/10.2136/vzj2018.08.0150

Guo L, Ning T, Nie L, Li Z, Lal R (2016) Interaction of deep placed controlled-release urea and water retention agent on nitrogen and water use and maize yield. Europ J Agronomy 75:118-129. https://doi.org/10.1016/j.eja.2016.01.010

Harter J, Guzman-Bustamante I, Kuehfuss S et al (2016) Gas entrapment and microbial $\mathrm{N}_{2} \mathrm{O}$ reduction reduce $\mathrm{N}_{2} \mathrm{O}$ emissions from a biochar-amended sandy clay loam soil. Sci Rep 6:39574. https://doi.org/10.1038/srep39574
Henry HAL (2008) Climate change and soil freezing dynamics: historical trends and projected changes. Clim Change 87:421-434. https://doi.org/10.1007/s10584-007-9322-8

Hothorn T, Bretz F, Westfall P (2008) Simultaneous inference in general parametric models. Biom J 50:346-363. https:// doi.org/10.1002/bimj.200810425

Huda A, Gaihre YK, Island MR, Singh U, Islam MR, Sanabria J, Abdus Satter M, Afroz H, Halder A, Jahiruddin M (2016) Floodwater ammonium, nitrogen use efficiency and rice yields with fertilizer deep placement and alternate wetting and drying under triple rice cropping systems. Nutr Cycl Agroecosyst 104:53-66. https://doi.org/10.1007/s10705015-9758-6

Jordbruksverket (2017) Production of cereals, dried pulses, oilseed crops, potatoes and temporary grasses in 2016 Final statistics (In Swedish) https://www.scb.se/contentassets/ 9e18f761698043c7b4c116e6650a19f2/jo0601_2016a01_ sm_jo16sm1701.pdf. Accessed 1 September 2019

Jordbruksverket (2018) Production of cereals, dried pulses, oilseed crops, potatoes and temporary grasses in 2017 Final statistics (In Swedish) http://www.jordbruksverket.se/download/18. 1849118116306152bd16899/1524827437079/

JO16SM1801.pdf Accessed 1 September 2019

Kautz T, Amelung W, Ewert F et al (2013) Nutrient acquisition from arable subsoils in temperate climates: a review. Soil Biol Biochem 57:1003-1022. https://doi.org/10.1016/j. soilbio.2012.09.014

Ke J, He R, Hou P, Ding C, Ding Y, Wang S, Liu Z, Tang S, Ding C, Chen L, Li G (2018) Combined controlled-released nitrogen fertilizers and deep placement effects of $\mathrm{N}$ leaching, rice yield and $\mathrm{N}$ recovery in machine-transplanted rice. Agric Ecosyst Environ 265:402-412. https:// doi.org/10.1016/j.agee.2018.06.023

Kelley KW, Sweeney DW (2007) Placement of preplant liquid nitrogen and phosphorus fertilizer and nitrogen rate affects no-till wheat following different summer crops. Agric J 99:1009-1017. https://doi.org/10.2134/agronj2006.0240

Kessel C, Venterea R, Six J, Adviento-Borbe MA, Linquist B, Groenigen KJ (2013) Climate, duration, and N placement determine $\mathrm{N}_{2} \mathrm{O}$ emissions in reduced tillage systems: a meta-analysis. Glob Change Biol 19:33-44. https://doi. org/10.1111/j.1365-2486.2012.02779.x

Kruger M, Frenzel P, Conrad R (2001) Microbial processes influencing methane emission from rice fields. Glob Change Biol 7:49-63. https://doi.org/10.1046/j.13652486.2001.00395.x

Lahda JK, Pathak H, Krupnik TJ, Six J, van Kessel C (2005) Efficiency of fertilizer nitrogen in cereal production: retrospects and prospects. Adv Agron 87:1-72. https://doi. org/10.1016/S0065-2113(05)87003-8

Li SX, Wang ZH, Hu TT, Gao YJ, Stewart BA (2009) Nitrogen in dryland soils of China and its management. Adv Agron 101:123-181. https://doi.org/10.1016/S00652113(08)00803-1

Linquist BA, Adviento-Borbe MA, Pittelkow CM, van Kessel C, van Groenigen KJ (2012) Fertilizer management practices and greenhouse gas emissions from rice systems: a quantitative review and analysis. Field Crops Res 135:10-21. https://doi.org/10.1016/j.fcr.2012.06.007

Liu XJ, Mosier AR, Halvorson AD, Zhang FS (2006) The impact of nitrogen placement and tillage on $\mathrm{NO}, \mathrm{N}_{2} \mathrm{O}, \mathrm{CH}_{4}$ 
and $\mathrm{CO}_{2}$ fluxes from a clay loam soil. Plant Soil 280:177-188. https://doi.org/10.1007/s11104-005-2950-8

Lotfollahi M, Alston AM, McDonald GK (1997) Effect of nitrogen fertiliser placement on grain protein concentration of wheat under different water regimes. Aust J Agric Res 48:241-250. https://doi.org/10.1071/A96066

Mengel DB, Nelson DW, Huber DM (1982) Placement of nitrogen fertilizers for no-till and conventional till corn. Agric J 74:515-518. https://doi.org/10.2134/agronj1982. $00021962007400030026 x$

Myhre G, Shindell D, Bréon F-M et al (2013) Anthropogenic and natural radiative forcing. In: Stocker TF et al (eds) Climate Change 2013: the physical science basis. Contribution of working group I to the fifth assessment report of the intergovernmental panel on climate change. Cambridge University Press, Cambridge, pp 659-740. https://www. ipcc.ch/site/assets/uploads/2018/02/WG1AR5_ Chapter08_FINAL.pdf

Nash PR, Motavalli PP, Nelson KA (2012) Nitrous oxide emissions from claypan soils due to nitrogen fertilizer source and tillage/fertilizer placement practices. Soil Sci Soc Am J 76:983-993. https://doi.org/10.2136/sssaj2011. 0296

Pan B, Lam SK, Mosier A, Luo Y, Chen D (2016) Ammonia volatilization from synthetic fertilizers and its mitigation strategies: a global synthesis. Agric Ecosyst Environ 232:283-289. https://doi.org/10.1016/j.agee.2016.08.019

Park S, Croteau P, Boering KA et al (2012) Trends and seasonal cycles in the isotopic composition of nitrous oxide since 1940. Nat Geosci 5:261-265. https://doi.org/10.1038/ Ngeo1421

Pinheiro J, Bates D, DebRoy S, Sarkar D, Core Team R (2019) nlme: linear and nonlinear mixed effects models. R package version 3.1-141. https://CRAN.R-project.org/ package $=$ nlme

Quemada M, Lassaletta L, Jensen LS, Godinot O, Brentrup F, Buckley C, Foray S, Hvid SK, Oenema J, Richards KG, Oenema O (2020) Exploring nitrogen indicators of farm performance among farm types across several European case studies. Agric Syst 177:102689. https://doi.org/10. 1016/j.agsy.2019.102689

Rath AK, Swain B, Ramakrishnan B, Panda D, Adhya TK, Rao VR, Sethinathan N (1999) Influence of fertilizer management and water regime on methane emission from rice fields. Agric Ecosyst Environ 76:99-107. https://doi.org/ 10.1016/S0167-8809(99)00080-8

Ravishankara AR, Daniel JS, Portmann RW (2009) Nitrous oxide $\left(\mathrm{N}_{2} \mathrm{O}\right)$ : the dominant ozone-depleting substance emitted in the 21st century. Sci 326:123-125. https://doi. org/10.1126/science. 1176985

Robinson CH (2002) Controls on decomposition and soil nitrogen availability at high latitudes. Plant Soil 242:65-81. https://doi.org/10.1023/A:1019681606112

RStudio Team (2018) RStudio: integrated development for R. RStudio, Inc., Boston.

Schimel JP (2018) Life in dry soils: effects of drought on soil microbial communities and processes. Annu Rev Ecol Evol Systemat 49:409-432. https://doi.org/10.1146/annurevecolsys-110617-062614

Schutz H, Holzapfel-Pschorn A, Conrad R, Rennenberg H, Seiler W (1989) A 3-year continuous record on the influence of daytime, season, and fertilizer treatment on methane emission rates from an Italian rice paddy. J Geophys Res 94(D13):16405-16416. https://doi.org/10.1029/ JD094iD13p16405

Setyanto P, Makarim AK, Fagi AM, Wassmann R, Buendia LV (2000) Crop management affecting methane emissions from irrigated and rainfed rice in Central Java (Indonesia). Nutr Cycl Agroecosyst 58:85-93. https://doi.org/10.1023/ A:1009834300790

Singh RA, Singh OP, Singh M (1976) Effect of soil compaction and nitrogen placement on weed population, yield and moisture use pattern of rainfed wheat. Plant Soil 44:87-96. https://doi.org/10.1007/bf00016958

Smith P, Bustamante M, Ahammad H et al (2014) Agriculture, forestry and other land use (AFOLU). In: Edenhofer O (ed) Climate change 2014: mitigation of climate change. Contribution of working group III to the fifth assessment report of the intergovernmental panel on climate change. Cambridge University Press, Cambridge, pp 811-922

United Nations, Department of Economic and Social Affairs, Population Division (2019) World Population Prospects 2019: Data Booklet. https://population.un.org/wpp/ Publications/Files/WPP2019_DataBooklet.pdf Accessed 1 Sep 2019

Venterea RT, Maharjan B, Dolan MS (2011) Fertilizer source and tillage effects on yield-scale nitrous oxide emission in a corn cropping system. J Env Qual 40:1521-1531. https:// doi.org/10.2134/jeq2011.0039

Wickham H (2016) ggplot2: elegant graphics for data analysis. Springer, New York

Wilke CO (2019) Cowplot: streamlined plot theme and plot annotations for 'ggplot2'. R package version 0.9.4. https:// CRAN.R-project.org/package $=$ cowplot

Wu M, Li G, Li W et al (2017) Nitrogen fertilizer deep placement for increased grain yield and nitrogen recovery efficiency in rice grown in subtropical China. Front Plant Sci 8:1227. https://doi.org/10.3389/fpls.2017.01227

Xia L, Lam SK, Chen D, Wang J, Tang Q, Yan X (2016) Can knowledge-based $\mathrm{N}$ management produce more staple grain with lower greenhouse gas emission and reactive nitrogen pollution? A meta-analysis. Glob Change Biol 23:1917-1925. https://doi.org/10.1111/gcb.13455

Xiang J, van Haden R, Peng S, Bouman BAM, Huang J, Cui K, Visperas RM, Zhu D, Zhang Y, Chen H (2013) Effect of deep placement of nitrogen fertilizer on growth, yield, and nitrogen uptake of aerobic rice. AJCS 7(6):870.877

Yao Z, Zheng X, Zhang Y, Liu C, Wang R, Lin S, Zuo Q, Butterbach-Bahl K (2017) Urea deep placement reduces yield-scaled greenhouse gas $\left(\mathrm{CH}_{4}\right.$ and $\left.\mathrm{N}_{2} \mathrm{O}\right)$ an NO emissions from a ground cover rice production system. Sci Rep 7:11415. https://doi.org/10.1038/s41598-017-11772-2

Zhu C, Xiang J, Zhang Y, Zhang Y, Zhu D, Chen H (2019) Mechanized transplanting with side deep fertilization increases yield and nitrogen use efficiency of rice in Eastern China. Sci Rep 9:5653. https://doi.org/10.1038/ s41598-019-42039-7

Publisher's note Springer Nature remains neutral with regard to jurisdictional claims in published maps and institutional affiliations. 